Dagmara Gut

\title{
Model postępowania sądowoadministracyjnego w Austrii
}

Artykuł dotyczy austriackiego modelu postępowania sądowoadministracyjnego, który na mocy noweli Verwaltungsgerichtsbarkeits-Novelle 2012 uległ istotnym zmianom. Od 2014 r. w Austrii funkcjonuje dwuinstancyjne sądownictwo administracyjne, obejmujące po jednym sądzie pierwszej instancji dla każdego kraju oraz dwa federalne sądy administracyjne pierwszej instancji. Sądem drugiej instancji został natomiast Trybunał Administracyjny. Zasadniczemu przekształceniu uległy także kompetencje orzecznicze sądów administracyjnych, które uzyskały możliwość podejmowania rozstrzygnięć merytorycznych. Co więcej, $\mathrm{z}$ powodu wprowadzenia sądów pierwszej instancji o uprawnieniach do orzekania merytorycznego, zdecydowano się na likwidację administracyjnego toku instancji. Rozwiązania przyjęte w Austrii wyznaczają kierunek rozwoju sądownictwa administracyjnego w Europie, mogą także stanowić źródło inspiracji dla polskiego ustawodawcy.

\section{Uwagi wstępne}

W literaturze wyróżnia się dwa podstawowe modele jurysdykcji sądowej w sprawach z zakresu administracji publicznej. Pierwszy to model tzw. pełnego orzekania, w którym dochodzi do merytorycznego rozpoznania sprawy w pełnym zakresie. Oznacza to, że sąd administracyjny $\mathrm{w}$ wyroku bezpośrednio rozstrzyga o uprawnieniu bądź obowiązku skarżącego. Drugi to model orzekania weryfikacyjnego, co do zasady kasacyjnego, w którym sąd administracyjny $\mathrm{W}$ przypadku uwzględnienia skargi nie ma kompetencji do bezpośredniego rozstrzygnięcia co do uprawnienia lub obowiązku skarżącego ${ }^{1}$.

Austriacki system sądownictwa administracyjnego uznawany jest za ojczyznę modelu orzekania kasacyjnego sądów administracyjnych ${ }^{2}$. Rozwiązania przyjęte w Austrii recypowano w wielu państwach europejskich, w tym również w Polsce ${ }^{3}$, gdzie w okresie

\footnotetext{
${ }^{1}$ Z. Kmieciak, Europejskie modele sądownictwa administracyjnego, ZNSA 2006, nr 4-5, s. 9.

${ }^{2}$ M. Kamiński, Orzekanie merytoryczne sądów administracyjnych. Uwagi na tle szwajcarskiego, austriackiego i niemieckiego systemu prawnego [w:] Przyszłość sadownictwa administracyjnego w Polsce z uwzględnieniem tendencji europejskich, red. I. Lipowicz, Z. Kmieciak, Warszawa 2012, s. 126.

${ }^{3}$ Zob. A. Kubiak-Kozłowska, Ewolucja $i$ ustrój sądownictwa administracyjnego w Polsce [w:] Polskie sądownictwo administracyjne, red. Z. Kmieciak, Warszawa 2006, s. 34 i n.; A. Krawczyk, Reforma sądownictwa administracyjnego w Austrii, PiP 2013, nr 4, s.137.
} 
międzywojennym powołano - na wzór sądownictwa austriackiego - jeden Najwyższy Trybunał Administracyjny.

Tradycyjny system co do zasady kasacyjnego orzekania funkcjonował w Austrii do końca 2013 r. ${ }^{5}$. Sądownictwo administracyjne zasadniczo skoncentrowane było wówczas w Trybunale Administracyjnym (Verwaltungsgerichtshof), który rozpoczął działalność w 1876 r. ${ }^{6}$. Był to organ jednoinstancyjny o kompetencjach głównie kasacyjnych. Oznacza to, że w przypadku uwzględnienia skargi mógł on podjąć wyrok, który bądź uchylał zaskarżoną decyzję, bądź stwierdzał jej nieważność. Niedopuszczalna była natomiast jakakolwiek treściowa zmiana decyzji lub jej zastąpienie ${ }^{7}$. Wyjątek w tym zakresie stanowiło orzekanie w sprawach o milczenie administracji (Säumnisbeschwerde), gdzie wyrok mógł zastąpić decyzję $^{8}$. Trybunał $\mathrm{w}$ tej kategorii spraw rozstrzygał bowiem zamiast organu administracyjnego, stosując przepisy prawa materialnego i procesowego, na podstawie których powinien orzec organ ${ }^{9}$. Inne wyjątki stanowiły również sytuacje przewidziane w przepisach szczególnych, na przykład w ustawie o prawie najmu ${ }^{10}$, które uprawniały sądy powszechne do dokonywania kontroli legalności działania administracji ${ }^{11}$. Zważywszy na generalne kompetencje orzecznicze tych sądów, mogą one - w przypadku uwzględnienia skargi - orzec co do istoty sprawy administracyjnej.

Obok Trybunału Administracyjnego do kontroli administracji publicznej uprawione były od 1988 r. organy o charakterze quasi-sądowym, tj. niezależne senaty administracyjne $\mathrm{w}$ krajach [związkowych] (UnabhängigeVerwaltungssenate in der Ländern) oraz Trybunał ds. Azylu (Asylgerichtshof) ${ }^{12}$. Ponadto właściwy do rozpoznawania skarg indywidualnych na decyzje administracyjne był także Trybunał Konstytucyjny

\footnotetext{
${ }^{4}$ Ustawa z 3.8.1922 r. o Najwyższym Trybunale Administracyjnym (Dz.U. Nr 67, poz. 600; t. j. Dz.U. z 1926 r. Nr 68, poz. 400, ze zm. - akt archiwalny).

${ }^{5}$ Verwaltungsgerichtsbarkeits-Novelle 2012, BGB1. Nr 51/2012. Zob. W. Piątek, A. Skoczylas, Geneza, rozwój $i$ model sadownictwa administracyjnego $w$ Polsce [w:]System prawa administracyjnego.Sadowa kontrola administracji publicznej, red. R. Hauser, Z. Niewiadomski, A. Wróbel, t. 10, Warszawa 2016, s. 62.

${ }^{6}$ J. Łętowski, Austria[w:] Sądownictwo administracyjne $w$ Europie Zachodniej, red. L. Garlicki, Warszawa 1990, s. 164.

${ }^{7}$ K. Sobierajski, Z problematyki sq̨downictwa administracyjnego $w$ Austrii, ZNSA 2006, nr 1, s. 168.

${ }^{8}$ Dopuszczalność tego typu wyroków była w przeszłości szeroko dyskutowana przez austriacką doktrynę. Obawiano się wykroczenia poza granicę kasacyjności orzekania Trybunału, poczytując ją jako naruszenie zasady podziału władz. Poglądy ówczesnej doktryny przytacza J. Łętowski, op. cit., s. 170. Szczegółowo skargę na bezczynność opisuje także M. Kamiński, op. cit., s. 127-128.

${ }^{9}$ K. Sobierajski, op.cit., s. 173.

${ }^{10}$ Sytuację tę przewiduje $\$ 40$ ustawy o prawie najmu (Bundesgesetzz 12.11.1981 r. überdasMietrecht [Mietrechtsgesetz-MRG], BGBI. 1981, s. 520 ze zm.); przykład ten przytacza K. Sobierajski, op. cit., s. 168 oraz W. Piątek, A. Skoczylas, op. cit., s. 62.

${ }^{11}$ Ustawy nadal mogą regulować kwestie orzekania merytorycznego przez sądy administracyjne, o czym później.

${ }^{12}$ Wprowadzone Bundes-Verfassungsgesetz-Novelle z 1988 r. (BGB1. Nr 685/1988, ost. zm. BGB1. Nr 2/2008. Kompetencje tych organów zostały wymienione w art. 129-136 B-VG Bundes-Verfassungsgesetz (B-VG), BGB1. Nr 1/1930) w kształcie obowiązującym przed 1 stycznia 2014 r.
} 
(Verfassungsgerichtschof). Uprawnienie to, z pewnymi modyfikacjami, przysługuje Trybunałowi do dziś. Na mocy art. 144 ust. 1 Bundes-Verfassungsgesetz (B-VG) ${ }^{13}$ Trybunał Konstytucyjny orzeka o skargach na orzeczenie sądu administracyjnego, jeżeli skarżący twierdzi, że orzeczeniem naruszono jego gwarantowane konstytucyjne prawo, albo jeżeli $\mathrm{W}$ wyniku zastosowania sprzecznego $\mathrm{z}$ ustawą rozporządzenia, niezgodnego $\mathrm{z}$ ustawą obwieszczenia o ogłoszeniu ustawy (umowy międzynarodowej), sprzecznej z Konstytucją ustawy bądź sprzecznej z prawem wewnętrznym umowy międzynarodowej naruszono jego prawa ${ }^{14}$. Do czasu rozprawy może on jednak odmówić rozpatrzenia skargi, jeżeli brak jest widoków na pomyślny wynik albo jej rozpatrzenie nie doprowadzi do wyjaśnienia zagadnienia konstytucyjnoprawnego (art. 144 ust. 2 B-VG).

Dyskusja nad reformą sądownictwa administracyjnego toczyła się w Austrii od lat. Jednoinstancyjność postępowania i kasacyjny charakter orzeczeń Trybunału Administracyjnego spotykały się z zarzutami naruszania zobowiązań międzynarodowych wynikających m.in. $\mathrm{z}$ Konwencji o ochronie praw człowieka i podstawowych wolności ${ }^{15}$ (art. 5, art. $6 \mathrm{i}$ art. 13) oraz z prawa unijnego (art. 47 Karty Praw Podstawowych ${ }^{16}$ ). Za niewystarczające uważano w tym zakresie powołanie wspomnianych senatów administracyjnych, $z$ racji faktu, że nie były to organy sądowe ${ }^{17}$. Nie bez znaczenia pozostawały także względy pragmatyczne związane ze znacznym obciążeniem Trybunału Administracyjnego ilością wpływających skarg ${ }^{18}$. Reakcją na powyższe było opracowanie projektu ustawy reformującej sądownictwo administracyjne w ramach programu rządowego „Sprawne państwo” (LeistungsfähigerStaat). Jego główne założenia oparte zostały o wcześniejsze inicjatywy, tj. projekt ekspercki z 2007 r (94/ME) oraz projekt nowelizacji Konstytucji (B-VG) z 2010 r. $(123 / 1)^{19}$. Po zaaprobowaniu go przez Komisję Konstytucyjną

\footnotetext{
${ }^{13}$ Bundes-Verfassungsgesetz der Republik Österreich (B-VG), BGB1. Nr 1/1930, ost. zm. BGB1. Nr BGB1. I Nr. 106/2016 (Federalna Ustawa Konstytucyjna Austrii).

${ }^{14}$ Tłum. Z. Kmieciak, P. Florjanowicz-Błachut, Austria - reforma sądownictwa administracyjnego. Wybór przepisów znowelizowanych 51. ustawa federalna, VerwaltungsgerichtsbarkeitsNowelle 2012, ZNSA 2013, nr 4, s. 197.

${ }^{15}$ Konwencja o ochronie praw człowieka i podstawowych wolności z 4.11 .1950 r. (Dz.U. z 1993 r. Nr 61, poz. 284, ze zm.).

${ }^{16}$ Karta praw podstawowych Unii Europejskiej (Dz.Urz.UE. 2016 Nr C 202/02).

${ }^{17}$ Z. Kmieciak, P. Florjanowicz-Błachut, op. cit., s. 188.

${ }^{18}$ A. Krawczyk, Merytoryczne orzekanie przez sady administracyjne $w$ Austrii w świetle założeń reformy sadownictwa administracyjnego (VerwaltungsgerichtsbarkeitsNowelle 2012), [w:] op. cit., red. I. Lipowicz, Z. Kmieciak, s.137; Z. Kmieciak, P. Florjanowicz-Błachut, op.cit., s. 188, K. Sobierajski, op.cit., s. 139.

${ }^{19}$ A. Krawczyk, Merytoryczne orzekanie..., s. 138; Regierungsvorlage - Verwaltungsgerichtsbarkeits-Novelle 2012 - projekt wraz z uzasadnieniem opublikowano na stronie: www.parlament.gv.at (dostęp z 14.5.2017 r.)
} 
projekt został uchwalony w 2012 r. jako „Verwaltungsgerichtsbarkeits-Novelle 2012”. Ustawę opublikowano w BGB1. Nr 51/2012 z 5.6.2012 r. ${ }^{20}$

Z uwagi na ustrojowy charakter ustawy nowelizującej, a co za tym idzie szeroką skalę zmian $\mathrm{w}$ niej przewidzianych, w ustawie nie ustalono jednolitego terminu wejścia $\mathrm{w}$ życie wszystkich postanowień (art. 151 ust. 51 pkt 6 B-VG) ${ }^{21}$. Skoro jednak najbardziej fundamentalne zmiany obowiązują od 1.1.2014 r., tę datę uważa się właśnie za granicę obowiązywania w Austrii kasacyjnego modelu postępowania sądowoadministracyjnego.

\section{Sądy administracyjne}

\subsubsection{Rodzaje sądów administracyjnych pierwszej instancji}

Jedną z najpoważniejszych zmian było utworzenie dwuinstancyjnego sądownictwa administracyjnego. Na mocy art. 129 B-BV w każdym kraju związkowym powołano jeden krajowy sąd administracyjny (Verwaltungsgericht des Landes), natomiast na poziomie federacji - jeden sąd administracyjny federacji pod nazwą Federalnego Sądu Administracyjnego (Verwaltungsgericht des Bunde), utworzony w miejsce Trybunału Azylowego (art. 151 ust.7 B-VG) oraz jeden sąd administracyjny federacji w sprawach finansowych pod nazwą Federalnego Sądu Finansowego (Verwaltungsgericht des BundesfürFinanzen). Dotychczasowy Trybunał Administracyjny stał się sądem II instancji, rozpatrującym kasacje od wyroków sądów administracyjnych (art. 133 ust. $1 \mathrm{~B}-\mathrm{VG}$ ).

Ze względu na utworzenie sądów administracyjnych pierwszej instancji zdecydowano się na likwidację administracyjnego toku instancji (z wyjątkiem spraw z zakresu działania gmin). Rozwiązano $\mathrm{w}$ związku $\mathrm{z}$ tym niezależne senaty administracyjne $\mathrm{w}$ krajach, Federalny Urząd Zamówień Publicznych (Bundesvergabeamt), niezależne senaty finansowe (tzw. niezależne organy administracyjne, unabhängigeVerwaltungsbehörden) oraz wymienione $\mathrm{w}$ załączniku dodanym po art. 152 B-VG pozostałe organy niezależne (sonstigeunabhängigeVerwaltungsbehörden), a zatem wszystkie federalne i krajowe organy

\footnotetext{
${ }^{20}$ Pełny tytuł ustawy to: Bundesgesetz, mit dem das Bundes-Verfassungsgesetz, das Finanz-Verfassungsgesetz 1948, das Finanzstrafgesetz, das Bundesgesetz, mit dem das Invalideneinstellungsgesetz 1969 geändert wird, das Bundessozialamtsgesetz, das Umweltverträglichkeitsprüfungsgesetz 2000, das Bundesgesetzblattgesetz, das Verwaltungsgerichtshofgesetz 1985 und das Verfassungsgerichtshofgesetz 1953 geändert und einige Bundesverfassungsgesetze und in einfachen Bundesgesetzen enthaltene Verfassungsbestimmungen aufgehoben werden (Verwaltungsgerichtsbarkeits-Novelle 2012).

${ }^{21} \mathrm{Z}$ punktu widzenia dzisiejszego Czytelnika nie jest konieczne dokładne omawianie tych przepisów.
} 
pełniące funkcję organów nadzoru i organów zwierzchnich, a także organów nadrzędnych $\mathrm{w}$ administracyjnym toku instancji ${ }^{22}$. Sprawy z zakresu właściwości tych organów zostały delegowane sądom administracyjnym pierwszej instancji (art. 151 ust. 51 pkt 8 B-VG). Postępowanie administracyjne w Austrii jest więc aktualnie jednoinstancyjne. Każdy organ w związku z tym stanowi pierwszą i ostatnią instancję, której decyzje są zaskarżalne do sądu administracyjnego.

\subsubsection{Zakres właściwości sądów administracyjnych pierwszej instancji}

Właściwość sądów administracyjnych pierwszej instancji obejmuje po pierwsze sprawy, które niegdyś rozpatrywane były przez odwoławcze organy administracyjne i poddane kognicji Trybunału Administracyjnego. Na mocy art. 130 ust. 1 B-VG sądy administracyjne orzekają w sprawach skarg: 1. na decyzję organu z powodu jej sprzeczności z prawem; 2. na wykonywanie bezpośrednich administracyjnoprawnych środków władczych o charakterze nakazu i przymusu z powodu ich sprzeczności z prawem; 3. na naruszenie obowiązku wydania decyzji przez organ administracyjny; 4. na wytyczne wydawane zgodnie $\mathrm{z}$ art. 81a ust. $4 \mathrm{~B}-\mathrm{VG}^{23}$. Dodatkowo, o czym mówi ust. 2 omawianego artykułu, ustawa federalna lub krajowa może przewidywać inną właściwość sądów administracyjnych do orzekania o: 1. skargach na sprzeczność z prawem działania organu administracji w wykonywaniu ustaw; 2. skargach na sprzeczność z prawem działania zamawiającego W sprawach z zakresu zamówień publicznych; 3. sporach w sprawach dyscyplinarnych urzędników publicznych ${ }^{24}$.

\subsubsection{Rozgraniczenie właściwości sądów administracyjnych pierwszej instancji}

Rozgraniczenie właściwości pomiędzy administracyjne sądy krajowe i federalne pierwszej instancji określone zostało w art. 131 ust. 1-3 B-VG. Właściwość krajowych sądów administracyjnych określona została za pomocą klauzuli generalnej - jeżeli ust. 2 i 3 nie stanowią inaczej sądy administracyjne krajów rozpoznają skargi zgodnie z art. 130 ust. 1, o którym była już mowa (art. 131 ust. 1 B-VG). Federalny Sąd Administracyjny zasadniczo rozpoznaje skargi w sprawach wykonawstwa federacji, które są załatwiane bezpośrednio

\footnotetext{
${ }^{22}$ A. Krawczyk, Merytoryczne orzekanie..., s. 139.

${ }^{23}$ Artykuł 81a ust B-VG dotyczy wytycznych wydawanych przez organy oświatowe (szkolne) federacji i ich zaskarżalności przed sądem administracyjnym.

24 Tłum. Z. Kmieciak, P. Florjanowicz-Błachut, op.cit., s. 191-192.
} 
przez organy federalne (art. 131 ust. 2 B-VG). Federalny Sąd Finansowy rozpoznaje skargi W sprawach danin publicznych (z wyjątkiem opłat administracyjnych federacji, krajów i gmin) i z zakresu prawa karnego skarbowego oraz w innych ustawowo określonych sprawach, o ile sprawy te są załatwione bezpośrednio przez organy podatkowe lub karne skarbowe federacji (art. 131 ust. 3 B-VG). Ustawa federalna może jednak przewidywać, za zgodą krajów, właściwość krajowych sądów administracyjnych w powyższych sprawach (z art. 131 ust. 2 i 3 B-VG) oraz w pozostałych sprawach wykonawstwa federacji, które nie są załatwiane bezpośrednio przez organy federalne (art. 131 ust. 4 pkt 1 oraz pkt 2 lit. b B-VG). Może również ustanawiać właściwość sądów administracyjnych federacji $\mathrm{w}$ sprawach oceny oddziaływania na środowisko dla przedsięwzięć, które mogą znacząco wpłynąć na środowisko (art. 133 ust. 4 pkt 2 lit. b) ${ }^{25}$.

\subsubsection{Skarga}

Skargę na decyzję organu administracyjnego z powodu sprzeczności z prawem może wnieść każdy, kto twierdzi, że przez wydanie decyzji naruszono jego prawa oraz w określonych przypadkach minister rządu federalnego (art. 132 ust. 1 pkt 1 i 2 B-VG). Podobnie skargę na wykonywanie przez organ administracyjny bezpośrednich działań władczych i przymusowych $\mathrm{z}$ powodu sprzeczności z prawem może wnieść każdy, kto twierdzi, że naruszyło ono jego prawa (art. 132 ust. 3 B-VG). Z powodu naruszenia obowiązku wydania rozstrzygnięcia skargę może wnieść każdy, kto jako strona W postępowaniu administracyjnym uważa się za uprawnionego do dochodzenia obowiązku wydania rozstrzygnięcia (art. 132 ust. 4 B-VG). Na wytyczne w sprawach z zakresu administracji szkolnej sprawę może wnieść organ szkolny na podstawie uchwały kolegium (art. 132 ust. 4 B-VG) ${ }^{26}$.

Zakres kognicji sądów administracyjnych pierwszej instancji ograniczony jest związaniem sądu treścią skargi ${ }^{27}$. W myśl $§ 27$ VwGVG, o ile sąd administracyjny nie stwierdzi niezgodności z prawem z powodu braku właściwości organu, poddaje badaniu zaskarżoną decyzję, zaskarżony nakaz, środek władzy lub polecenie w zakresie wyznaczonym skargą, czyli przytoczonymi podstawami skargi, zakresem żądania oraz zakresem zaskarżenia (§ 9 ust. 1 zd. 3 i 4 oraz ust. 3 VwGVG). Oznacza to, że skarżący po wniesieniu skargi nie

\footnotetext{
${ }^{25}$ Thum. Ibidem, s. 193.

${ }^{26}$ Thum. Z. Kmieciak, P. Florjanowicz-Błachut, op. cit., s. 193.

${ }^{27}$ P. Ostojski, op. cit., s. 83.
} 
może już rozszerzyć bądź zmienić jej treści, jak również że sąd administracyjny nie może z urzędu stwierdzić naruszeń prawa niepowołanych w skardze. Nie dotyczy to sytuacji, w której zachodzi niewłaściwość organu (rzeczowa, funkcjonalna, miejscowa $\S 27$ in principio VwGVG), wówczas sąd administracyjny jest bowiem obowiązany uwzględnić skargę.

\subsubsection{Rozstrzygnięcia sądów administracyjnych pierwszej instancji}

Kolejną bardzo istotą zmianą jest przyznanie sądom administracyjnym pierwszej instancji kompetencji do orzekania merytorycznego. W sprawach karno-administracyjnych wydanie rozstrzygnięcia co do meritum sprawy jest obligatoryjne (art. 130 ust. 4 in principio B-VG: o skargach, o których mowa w [art. 130] ust. 1 pkt 1, w sprawach karno-administracyjnych sąd administracyjny orzeka w sprawie samodzielnie). Natomiast $\mathrm{w}$ pozostałych sprawach na podstawie art. 130 ust. 1 pkt 1 B-VG sąd administracyjny orzeka w sprawie samodzielnie, jeżeli: 1. stan faktyczny sprawy nie budzi wątpliwości albo 2. samodzielne ustalenie stanu faktycznego sprawy przez sąd administracyjny jest uzasadnione względami szybkości bądź związane jest ze znaczną oszczędnością kosztów ${ }^{28}$ (art. 130 ust. 4 in fine B-VG). W uzasadnieniu projektu ustawy Verwaltungsgerichtsbarkeits-Novelle 2012 wskazano, że przepis ten reguluje wyłącznie orzekanie w sprawach na decyzje i określa przypadki, w których sąd jest obowiązany do orzeczenia merytorycznego. Podkreślono, że tam, gdzie przewidziano obligatoryjne orzekanie merytoryczne sądowi nie wolno orzekać kasacyjnie ${ }^{29}$. Co więcej, z orzecznictwa Trybunału Administracyjnego wynika, że rozstrzygnięcie przez sąd skargi na decyzję w sposób kasacyjny powinno zachodzić w wyjątkowych przypadkach. Może ono nastąpić „W razie jaskrawych i znaczących luk w materiale dowodowym sprawy, kiedy organ administracji publicznej zaniechał przeprowadzenia postępowania dowodowego bądź gdy podjął czynności, które tylko $\mathrm{w}$ niewielkim stopniu przyczyniły się do ustalenia stanu faktycznego sprawy ${ }^{30}$ ". Można w związku z tym przyjąć, że w odniesieniu do skarg

\footnotetext{
${ }^{28}$ Tłum. Z. Kmieciak, P. Florjanowicz-Błachut, op.cit., s. 192.

${ }^{29} 1618$ der Beilagen XXIV. GP - Regierungsvorlage - Vorblatt und Erläuterungen, https://www.parlament.gv.at/PAKT/VHG/XXIV/I/I_01618/fname_238643.pdf, dostęp z 5.3.2017 r., s. 14.

${ }^{30}$ R. Winkler, Vorrang der reformatorischen Sachentscheidung - VwGH 26.6.2014, Ro 2014/03/0063, ZVG 2014, nr 5, s. 437.
} 
na decyzje ustrojodawca austriacki jako regułę przyjął obowiązek ich rozstrzygnięcia przez sądy co do istoty sprawy ${ }^{31}$.

W stosunku do pozostałych typów skarg to ustawodawcy zwykłemu pozostawiona została swoboda co do sposobu uregulowania ich rozstrzygnięcia. Dopuszczono również możliwość wprowadzenia dalszych przypadków merytorycznego orzekania w sprawach na decyzje w przepisach ustawowych. W $\S 28$ ust. 2Verwaltungsgerichtsverfahrensgesetz (VwGVG) 32 powtórzone zostało dosłowne brzmienie dwóch przesłanek $\mathrm{z}$ art. 130 ust. 4 B-VG, uzależniających wydanie orzeczenia co do istoty przez sąd administracyjny. Dodano natomiast możliwość orzekania merytorycznego nawet w przypadku niewystąpienia którejkolwiek $\mathrm{z}$ podstaw $\mathrm{z} \S 28$ ust. 2, jeżeli organ, którego decyzja została zaskarżona przy wniesieniu skargi, nie wyraził sprzeciwu odnośnie do wydania orzeczenia co do istoty przez sąd, mając na uwadze istotne uproszczenie oraz przyśpieszenie postępowania administracyjnego (\$28 ust. 3 VwGVG). Podobna konstrukcja zastosowana została w odniesieniu do decyzji uznaniowych (art. 28 ust. 4 VwGVG). W tym przypadku jednak sąd administracyjny nie może zmienić decyzji ze względu na jej niecelowość (unzweckmäßigeErmessensübung), a może ją jedynie uchylić i przekazać sprawę do ponownego rozpoznania ${ }^{33}$.

W przypadku skargi na wykonywanie bezpośrednich administracyjnoprawnych środków władczych o charakterze nakazu i przymusu z powodu sprzeczności z prawem (art. 130 ust. 1 pkt 2 B-VG) uznanie zaskarżonego aktu za sprzeczny z prawem skutkuje jego uchyleniem przez sąd (art. 28 ust. 6 VwGVG). Natomiast w przypadku skarg dotyczących wytycznych wydawanych przez organy oświatowe (szkolne) federacji (art. 130 ust. 1 pkt 4 B-VG) sąd administracyjny rozstrzyga zawsze kasacyjne (art. 28 ust. $8 \mathrm{VwGVG).}$

W odniesieniu do skarg na naruszenie obowiązku wydania decyzji przez organ administracyjny (art. 130 ust. 1 pkt 3 B-VG) sąd, uznając skargę za zasadną, w pierwszej kolejności ogranicza się do kwestii prawnych o znaczeniu podstawowym i wydaje wyrok wstępny, nakładając na organ administracji obowiązek podjęcia decyzji w terminie nieprzekraczającym maksymalnie ośmiu tygodni, z uwzględnieniem wyrażonego poglądu

\footnotetext{
${ }^{31}$ P. Ostojski, Wykonywanie wyroków sądowoadministracyjnych w Austrii [w:] Wykonywanie wyroku sądu administracyjnego, red. W. Piątek, Warszawa 2017, s. 84.

${ }^{32}$ Bundesgesetz über das Verfahren der Verwaltungsgerichte (Verwaltungsgerichtsverfahrensgesetz - VwGVG), BGB1. I Nr 33/2013, ost. zm. BGB1. I Nr 24/2017 (austriacka ustawa o postępowaniu sądowoadministracyjnym).

${ }^{33}$ P. Ostojski, op.cit., s. 86 i podana tam literatura.
} 
prawnego (Rahmenentscheidung) ${ }^{34}$. Jeśli organ nie wykona nakazu z wyroku wstępnego, wówczas sąd musi orzec co do istoty spawy (§ 28 ust. 7 VwGVG). Niezależnie jednak od tej procedury sąd administracyjny może od razu załatwić sprawę za organ administracyjny ${ }^{35}$.

\subsection{Trybunal Administracyjny}

\subsubsection{Właściwość Trybunału Administracyjnego}

Nowelizacja sądownictwa administracyjnego z 2012 r. znacząco zmieniła również właściwość Trybunału Administracyjnego. Artykuł 133 ust. 1 B-VG stanowi, że rozpoznaje on rewizje od orzeczenia sądu administracyjnego $\mathrm{z}$ powodu sprzeczności $\mathrm{z}$ prawem; wnioski o wyznaczenie terminu z powodu naruszenia przez sąd administracyjny obowiązku wydania rozstrzygnięcia; spory kompetencyjne między organami administracji lub między sądem administracyjnym a Trybunałem Administracyjnym. Dodatkowo, ustawa federalna lub krajowa mogą przewidywać właściwość Trybunału Administracyjnego do orzekania w sprawach wniosków sądu powszechnego o stwierdzenie sprzeczności z prawem decyzji administracyjnej lub orzeczenia sądu administracyjnego (art. 133 ust. 2 B-VG). Z zakresu właściwości Trybunału Administracyjnego wyłączone zostały sprawy należące do właściwości Trybunału Konstytucyjnego (art. 133 ust. 5 B-VG) ${ }^{36}$.

\subsubsection{Rewizja}

Dopuszczalność wniesienia rewizji od rozstrzygnięcia sądu administracyjnego jest daleko ograniczona. Warunkuje ją konieczność wyjaśnienia kwestii prawnej o zasadniczym znaczeniu, w szczególności w sytuacji, gdy [zaskarżone] orzeczenie odbiega od orzecznictwa Trybunału Administracyjnego; brak jest takiego orzecznictwa; albo pozostaje do wyjaśnienia zagadnienie prawne $\mathrm{w}$ dotychczasowym orzecznictwie Trybunału Administracyjnego nie zostało jeszcze rozstrzygnięte (art. 133 ust. 4 B-VG). Dodatkowo, w przypadku, gdy orzeczenie ma za przedmiot niewielką sumę pieniężną, ustawą federalną może zostać przewidziane, że rewizja jest niedopuszczalna (art. 133 ust. 4 in fine B-VG) ${ }^{37}$.

\footnotetext{
${ }^{34}$ P. Ostojski, op. cit., s. 87.

${ }^{35}$ Ibidem, 87.

${ }^{36}$ Tłum. Z. Kmieciak. P. Florjanowicz-Błachut, op. cit., s. 193-194.

${ }^{37}$ Ibidem, s. 194.
} 
Rewizję od orzeczenia sądu administracyjnego może wnieść z powodu sprzeczności z prawem: każdy, kto twierdzi, że orzeczenie naruszyło jego prawa; skarżony organ w postępowaniu przed sądem administracyjnym; właściwy minister federalny w sprawach wymienionych w art. 132 ust. 1 pkt 2 B-VG; organ szkolny na podstawie uchwały kolegium w sprawach wymienionych w art. 132 ust. 4 B-VG (art. 133 ust. 6 B-VG) ${ }^{38}$. Sprzeczność z prawem może odnosić się do każdego rodzaju przepisów prawnych, które determinowały zaskarżone orzeczenie ${ }^{39}$.

\subsubsection{Rozstrzygnięcia Trybunału Administracyjnego}

Trybunał Administracyjny może: 1. uznać rewizję za nieuzasadnioną i ją oddalić; 2. uwzględnić rewizję i uchylić zaskarżony wyrok lub postanowienie bądź orzec co do istoty sprawy, o czym później ( $\$ 42$ ust. $1 \mathrm{VwGG}^{40}$ ). Uchylenie zaskarżonego rozstrzygnięcia może nastąpić, jeżeli zachodzi sprzeczność z prawem orzeczenia albo z powodu braku właściwości sądu administracyjnego (§ 42 ust. 2 pkt 1 i 2 VwGG). Sprzeczność z prawem może odnosić się zarówno do przepisów materialnoprawnych, jak i do przepisów procesowych, w tym może dotyczyć błędnej wykładni lub błędnej oceny prawnej ${ }^{41}$. Ze względu na przeważająco kasacyjny charakter orzeczeń Trybunału Administracyjnego na szczególną uwagę zasługują przesłanki naruszenia przepisów postępowania przez sądy administracyjne pierwszej instancji, gdyż to one najczęściej skutkują uchyleniem zaskarżonego wyroku lub postanowienia $^{42}$. Mianowicie naruszenie przepisów proceduralnych może polegać na: ustaleniu stanu faktycznego przez sąd w sposób istotnie odbiegających od akt sprawy (§ 42 ust. 2 pkt 3 lit a VwGG); konieczności uzupełnienia $\mathrm{w}$ istotnym stopniu stanu faktycznego sprawy ( $\$ 42$ ust. 2 pkt 3 lit. b VwGG); stwierdzeniu, że działanie przez sąd $\mathrm{w}$ zgodzie $\mathrm{z}$ przepisami postępowania doprowadziłoby do wydania odmiennego wyroku bądź postanowienia ( $\$ 42$ ust. 2 pkt 3 lit. c VwGG).

Poza klasyczną, kasacyjną formułą orzekania Trybunał Administracyjny może również podejmować rozstrzygnięcia merytoryczne. Na mocy § 42 ust. 3a VwGG Trybunał Administracyjny może samodzielnie [merytorycznie] orzec w sprawie, jeżeli dojrzała ona

\footnotetext{
${ }^{38}$ Ibidem, s. 194.

${ }^{39}$ P. Ostrojski, op.cit., s. 88.

${ }^{40}$ Verwaltungsgerichtshofgesetz 1985 - VwGG, BGB1. Nr 10/1985, ost. zm. BGB1. I Nr. 24/2017 (ustawa o Trybunale Administracyjnym w Austrii).

${ }^{41}$ Wyrok Trybunału Administracyjnego z 26.6.1992, 91/16/0057, https:/www.ris.bka.gv.at, cytowany także przez: P. Ostojski,op. cit., s. 88.

${ }^{42}$ P. Ostojski, op. cit., s. 88.
} 
do rozstrzygnięcia i samodzielne rozstrzygnięcie w sprawie jest uzasadnione względami prostoty, celowości i oszczędności kosztów ${ }^{43}$. W takiej sytuacji Trybunał powinien dokonać ustaleń faktycznych, w tym celu może zlecić sądowi administracyjnemu pierwszej instancji uzupełnienie postępowania wyjaśniającego (§ 42 ust. 4 VwGG).

Uwzględnienie rewizji i wydanie właściwego rozstrzygnięcia obliguje sąd pierwszej instancji, a w przypadkach orzeczeń merytorycznych - organy administracyjne, do respektowania oceny prawej Trybunału Administracyjnego ( $\$ 63$ ust. 1 VwGG) ${ }^{44}$.

\section{Wykonywanie wyroków sądów administracyjnych}

Warunkiem wykonania wyroku sądu administracyjnego jest jego uprawomocnienie się. W przypadku oddalenia skargi strona skarżąca zobowiązana jest wykonać obowiązek lub zrealizować uprawnienie określone w akcie lub środku władczym pochodzącym od organu administracji publicznej ${ }^{45}$. Natomiast w przypadku uwzględnienia skargi wykonanie wyroków sądów wygląda odmiennie w zależności od jego charakteru. Wykonanie wyroku merytorycznego przebiega w taki sam sposób jak wykonanie decyzji wydanej przez organ administracji publicznej, mianowicie to adresat rozstrzygnięcia realizuje swoje uprawnienie bądź obowiązek. Wykonanie wyroku kasacyjnego w przypadku uchylenia decyzji nakłada na organy administracji obowiązek niezwłocznego ustanowienia stanu prawnego odpowiadającego ocenie prawnej zaprezentowanej przez sąd w tym orzeczeniu ( 28 ust. 5 VwGVG). Oznacza to, podobnie jak w polskim postępowaniu sądowoadministracyjnym, konieczność wydania decyzji, treściowo zgodnej z poglądem sądu (§ 28 ust. 3 i 4 VwGVG).

\section{Podsumowanie}

Reforma sądownictwa administracyjnego w Austrii jest współcześnie najlepszym europejskim przykładem przemyślanego i systemowego odejścia od orzekania kasacyjnego sądów administracyjnych. Wyrosła $\mathrm{z}$ formuły czysto kasacyjnej kontrola administracji

\footnotetext{
${ }^{43}$ Tłum. Z. Kmieciak, P. Florjanowicz-Błachut, op.cit, s. 200.

${ }^{44}$ P. Ostojski, op.cit., s. 90.

${ }^{45}$ Ibidem, s. 90.
} 
publicznej uzyskała obecnie na wskroś odmienny kształt, co w literaturze postrzega się jako „kierunek naturalnej drogi rozwoju sądownictwa administracyjnego w Europie"46.

Od lat zwraca się bowiem uwagę na niską efektywność modelu orzekania kasacyjnego ${ }^{47}$. Dotyczy ona zwłaszcza trudności w prawidłowym wykonywaniu wyroków sądów administracyjnych. Organy administracji publicznej nierzadko nie chcą uznać wskazanego przez sąd kierunku wykładni przepisu prawa będącego podstawą rozstrzygnięcia bądź nie przestrzegają zaleconych przez sąd wymagań przeprowadzenia postępowania rozpoznawczego $\mathrm{w}$ sprawie ${ }^{48}$. Prowadzi to często do powrotu tej samej sprawy do sądu administracyjnego, co w literaturze nazywane jest efektem jo-jo ${ }^{49}$. W tym zakresie wskazuje się także na problem przewlekłości postępowania, gdyż w rozumieniu Europejskiego Trybunału Praw Człowieka do czasu postępowania wlicza się zarówno postępowanie przed sądem, jak też przed organem administracji publicznej ${ }^{50}$

W rodzimej doktrynie asumpt do pogłębionej dyskusji dotyczącej merytorycznego orzekania przez sądy administracyjne stworzyła nowelizacja ustawy Prawo o postępowaniu przed sądami administracyjnymi z 9.4.2015 r. ${ }^{51}$, która wprowadziła kilka istotnych zmian odnoszących się do rozszerzenia zakresu kompetencji orzeczniczych sądów administracyjnych w postaci możliwości podejmowania wyroków merytorycznych. W uzasadnieniu projektu wskazano, że główną motywacją wprowadzonych zmian była chęć uproszczenia, usprawnienia i zapewnienia szybkości postępowania przed sądami administracyjnymi $^{52}$. Co prawda, także przed wejściem w życie noweli kwietniowej sądy administracyjne były wyposażone $\mathrm{w}$ kompetencje do merytorycznego orzekania, jednak uprawnienia te miały wąski charakter przedmiotowy (art. $146 \S 2$ ustawy z 30.8.2002 r. Prawo o postępowaniu przed sądami administracyjnymi ${ }^{53}$ dotyczący wyłącznie aktów i czynności z art. $3 \S 2$ pkt 4p.p.s.a. oraz art. $154 \S 2$ p.p.s.a. dotyczący niewykonania wyroku uwzględniającego skargę na bezczynność lub przewlekłe prowadzenie postępowania).

\footnotetext{
${ }^{46}$ A Krawczyk, Merytoryczne orzekanie..., s. 143.

${ }^{47}$ Z. Kmieciak, Postępowanie administracyjne i sqdowoadministracyjne a prawo europejskie, Warszawa 2010, s. 105.

${ }^{48}$ R. Hauser, Wstępne założenia nowelizacji ustawy - Prawo o postępowaniu przed sądami administracyjnymi, PiP 2001, z. 2, s. 20-21.

${ }^{49}$ Z. Kmieciak, Postepowanie administracyjne..., s. 109.

${ }^{50}$ A. Skoczylas, Stan i obecne problemy sadownictwa administracyjnego w Polsce [w:] op. cit., red. I. Lipowicz, Z. Kmieciak, s. 13 .

${ }^{51}$ Dz.U. poz. 658, dalej jako ustawa nowelizująca lub nowela kwietniowa.

${ }^{52}$ Sejm VII kadencji, druk sejmowy nr 1633, s. 3.

${ }^{53}$ Ustawa z 30.8.2002 r. Prawo o postępowaniu przed sądami administracyjnymi, t.j. Dz.U z 2012 r. Nr 153, poz. 270, ze zm. (dalej jako: p.p.s.a.).
} 
$\mathrm{Na}$ mocy noweli kwietniowej dodano art. 145a, przewidujący najszerszy dotąd zakres, w którym sąd administracyjny może podejmować rozstrzygnięcia co do istoty sprawy. Mianowicie w przypadku uchylenia decyzji lub postanowienia (w całości bądź w części) ze względu na naruszenie przez organ administracji prawa materialnego, które miało wpływ na wynik sprawy (art. $145 \S 1$ pkt 1 lit. a p.p.s.a.), a także w przypadku stwierdzenia nieważności decyzji lub postanowienia (w całości lub w części), gdy zachodzą przyczyny określone w art. 156 ustawy z 14.6.1960 r. - Kodeks postępowania administracyjnego ${ }^{54}$ lub $\mathrm{w}$ innych przepisach, sąd obligatoryjnie powinien zobowiązać organ administracji publicznej do wydania w określonym terminie decyzji lub postanowienia, wskazując przy tym sposób załatwienia sprawy lub jej rozstrzygnięcie. Warunkami niezbędnymi do zaktualizowania się obowiązku sądu są jednak: występowanie okoliczności sprawy, które uzasadniają taką decyzję, czyli niesporne okoliczności faktyczne danej sprawy oraz niesporny stan prawny (przesłanka ocenna), jak również fakt, że dane rozstrzygnięcie nie jest pozostawione przez ustawodawcę uznaniu administracji publicznej (przesłanka bezwzględna) $)^{55}$. Zauważyć należy jednak, że wyrok sądu zobowiązujący organ administracji publicznej do wydania decyzji lub postanowienia określonej treści nie jest sensu stricto wyrokiem merytorycznym. Sąd w tym przypadku nie orzeka bowiem w sposób bezpośredni o uprawnieniach bądź obowiązkach skarżącego, wskazuje jedynie jak powinien rozstrzygnąć organ. Dopiero na mocy $\S 3$ omawianego artykułu, jeśli organ nie wyda w określonym przez sąd terminie decyzji lub postanowienia oraz w wyniku wniesienia przez stronę skargi z żądaniem wydania przez sąd orzeczenia stwierdzającego istnienie albo nieistnienie uprawnienia lub obowiązku sąd ten może rozstrzygnąć sprawę merytorycznie, to znaczy $\mathrm{w}$ wyroku określić bezpośrednio istnienie albo nieistnienie uprawnienia lub obowiązku skarżącego. Art. 145a p.p.s.a. jest zatem istotnym odstępstwem od reguły kasacyjnego charakteru orzeczeń sądów administracyjnych, jednak w praktyce sądy te niezwykle rzadko korzystają $\mathrm{z}$ kompetencji w nim przewidzianych. Jak wynika z Informacji o działalności sądów administracyjnych ${ }^{56}$ sądy te w 2016 r. podjęły dwa rozstrzygnięcia na podstawie $145 \mathrm{a} \S 1$ p.p.s.a., czyli rozstrzygnięcia zobowiązujące organy administracji publicznej do podjęcia decyzji lub postanowienia określonej treści.

\footnotetext{
${ }^{54}$ Ustawa z 14.6.1960 r. Kodeks postępowania administracyjnego, t.j. Dz. U z 2016, poz. 23, ze zm. (dalej jako: k.p.a.).

${ }^{55}$ P. Jagielski, Komentarz do art. 145 a p.p.s.a., [w:] Prawo o postęowaniu przed sądami administracyjnymi. Komentarz, red. R. Hauser, M. Wierzbowski, Warszawa 2015, s. 602.

${ }^{56}$ Sprawozdania są dostępne na stronie internetowej Naczelnego Sądu Administracyjnego (www.nsa.gov.pl), dostęp z 14.5.2017 r.
} 
Nie zapadł zatem ani jeden wyrok, w którym sąd rozstrzygałby bezpośrednio o obowiązkach lub uprawnieniach skarżącego.

Drugim przepisem wartym w tym zakresie uwagi, jest $\S 3$ dodany w art. 145 p.p.s.a. $\mathrm{Na}$ jego podstawie $\mathrm{w}$ przypadku, gdy sąd administracyjny, uchylając decyzję lub postanowienie w całości lub w części (art. $145 \S 1$ pkt 1 p.p.s.a.), albo stwierdzając nieważność decyzji lub postanowienia w całości lub w części (art. $145 \S 1$ pkt 2 p.p.s.a.), stwierdzi dodatkowo występowanie podstawy do umorzenia postępowania administracyjnego ${ }^{57}$, zobowiązany jest do jednoczesnego umorzenia takiego postępowania ${ }^{58}$. We wcześniejszym stanie prawnym po uchyleniu lub stwierdzeniu nieważności zaskarżonej decyzji lub postanowienia przez wojewódzki sąd administracyjny umorzenie postępowania należało wyłącznie do kompetencji organu administracji publicznej. Obecnie orzeczenie wydane na podstawie art. $145 \S 3$ p.p.s.a. zastępuje rozstrzygnięcie organu administracji publicznej, w tym zakresie pełniąc funkcję decyzji umarzającej postępowanie administracyjne w całości lub w części. Pomimo, że umorzenie postępowania administracyjnego ujmowane jest przez przedstawicieli doktryny raczej jako akt o charakterze formalnym, który nie rozstrzyga sprawy administracyjnej co do istoty, nie można wykluczyć, że w wyjątkowych przypadkach decyzja o umorzeniu postępowania administracyjnego wywiera skutki materialnoprawne ${ }^{59}$. W związku z tym przedmiotową zmianę można poczytywać za swoiste odstępstwo od reguły kasacyjnego orzekania przez sądy administracyjne ${ }^{60}$.

Kompetencje polskich sądów administracyjnych do podejmowania rozstrzygnięć merytorycznych są, jak wynika z powyższego, dużo węższe, niżeli ma to miejsce w Austrii, gdzie sądy administracyjne obecnie wydają głównie wyroki merytoryczne. Ponadto w Polsce przyjęto konstrukcję, według której sądy administracyjne powinny najpierw zobowiązać organy administracji publicznej do wydania decyzji lub postanowienia o określonej treści, a dopiero w przypadku niewykonania tego obowiązku sądy te mogą rozstrzygnąć sprawę co do istoty (art. 145a p.p.s.a.).

W ocenie dopuszczalności pod względem zgodności z Konstytucją Rzeczypospolitej Polskiej ${ }^{61}$ rozwiązań przyjętych $\mathrm{w}$ noweli kwietniowej polska doktryna jest istotnie podzielona. Krytycy koncepcji modernizacji formuły orzekania przez polskie sądy

\footnotetext{
${ }^{57} \mathrm{Z}$ art. $105 \S 1$ k.p.a.

${ }^{58}$ P. Jagielski, Komentarz do art. 145 p.p.s.a., [w:] op. cit., s.598.

${ }^{59}$ W. Piątek, Nowe kompetencje do merytorycznego orzekania przez sady administracyjne, PiP 2017, z. 1, s. 22.

${ }^{60}$ Artykuł 145a p.p.s.a. oraz art. $145 \S 3$ p.p.s.a. nie są jedynymi przepisami, na mocy których sąd administracyjny może podejmować rozstrzygnięcia merytoryczne. Są to jednak regulacje zasługujące na największą uwagę ze względu na to, że przewidują najszersze kompetencje $w$ tym zakresie. Por. art. $149 \S 1$ pkt 2 i $\S 1$ b.

${ }^{61}$ Konstytucja Rzeczypospolitej Polskiej z 7.4.1997 r., Dz.U. Nr 78, poz. 483, ze zm.
} 
administracyjne wskazują, że merytoryczne orzekanie przez sądy administracyjne jest niezgodne $\mathrm{z}$ art. 184 Konstytucji, który, zakreślając ramy orzekania przez sądy administracyjne, zawęził je do kontroli działalności administracji publicznej oraz z art. 10 ust. 1 Konstytucji, gwarantującym trójpodział władzy w Rzeczypospolitej Polskiej ${ }^{62}$. Zwolennicy podkreślają natomiast, że sposób pojmowania kontroli realizowanej przez sądy administracyjne w doktrynie europejskiej znacząco się zmienił. A co za tym idzie odmiennie patrzy się także na zasadę podziału władz, która nie jest postrzegana jako wartość absolutna, zaś podział na władzę ustawodawczą, wykonawczą i sądowniczą ma charakter dynamiczny i wieloaspektowy ${ }^{63}$. Zdaniem Z. Kmieciaka ,przesadne przywiązanie do kasacyjnej formuły orzekania przez sądy administracyjne, uzasadniane koniecznością respektowania

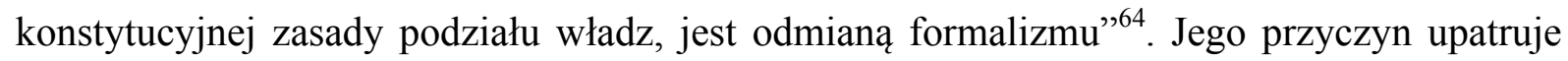
się w fałszywym pojmowaniu idei oddzielenia od siebie władzy sądowniczej i wykonawczej. Jak pisze holenderski badacz S. Jansen „stan równowagi pomiędzy nimi [władzą sądowniczą i wykonawczą] uległby zakłóceniu nie w przypadku przyznania sądom administracyjnym kompetencji do merytorycznego orzekania, a w razie pozbawiania władzy sądowniczej możliwości silniejszego oddziaływania na sprawy władzy wykonawczej ${ }^{65}$.

Swoistą pointą powyższych rozważań uczynić można słowa austriackiego ministra Lassera z 1875 r., który komentując ustawę wprowadzającą sądownictwo administracyjne, mówił: „administracja austriacka - zresztą każda administracja, która działa w takich warunkach i strukturach jak nasza, może znieść sąd administracyjny, jako organ kasacyjny, ale nie sąd, który miałby merytorycznie orzekać w sprawach, w których ostatnie słowo musi należeć do właściwego ministra. Taki sąd musiałby sam administrować, a to jest nie do pomyślenia i nie do zrealizowania; to po prostu - co nie wymaga żadnego dowodu - to po prostu nie wyjdzie!”66. Jak widać prognozy ministra nie sprawdziły się, a austriackie sądy od blisko trzech lat podejmują rozstrzygnięcia merytoryczne. Być może także w Polsce, pomimo aktualnych sprzeciwów części doktryny, sądy administracyjne uzyskają jeszcze

\footnotetext{
${ }^{62}$ Poglądy doktryny w tym zakresie szczegółowo omawia Z. Kmieciak [w:] Z. Kmieciak, Efektywność ochrony udzielanej przez sady administracyjne [w:] idem, Polskie sadownictwo administracyjne - zarys systemu, Warszawa 2015, s. 323 i nast.

${ }^{63}$ Ibidem, s. 327.

${ }^{64}$ Ibidem,s. 330.

${ }^{65}$ S. Jansen, Towards and Adjustment of the TriasPolitica: The Administrative Courts as (Procedural) Lawmaker; A study of the Influence of the European Human Rights Convention and the Case Law by the European Court of Human Fights on the TriasPolitica, in Particular the Position of Dutch Administrative Courts in Relation to the Administration, [w:] red. F. Stroink, E. van der Linden, Judicial Lawmaking and Administrative Law, Antwerpen-Oxford 2005, s. 54. Myśl tę przytacza także Z. Kmieciak, Efektywność ochrony...., s. 330.

${ }^{66}$ J. Łętowski, op. cit., s. 164.
} 
szerszą możliwość orzekania co do istoty sprawy. Jak wynika bowiem z bieżących doświadczeń, przewidziane $\mathrm{w}$ noweli kwietniowej rozszerzone uprawnienia orzecznicze nie są przez sądy wykorzystywane. Wynika to zapewne z przywiązania sądów do kasacyjnej formuły orzekania oraz z faktu, że obecne uprawnienia do podejmowania merytorycznych rozstrzygnięć są daleko ograniczone. Mając to na uwadze uważam, że dopiero wprowadzenie dalej idących uprawnień do orzekania co do istoty sprawy przez sądy administracyjne, tak, jak ma to miejsce $\mathrm{w}$ Austrii, spowodowałoby urzeczywistnienie celów, które przyświecały polskiemu ustawodawcy przy nowelizacji z 2015 r. Być może w tym zakresie bieżące doświadczenia austriackie ponownie, jak miało to miejsce $\mathrm{w}$ okresie międzywojennym, stanowić mogłyby źródło inspiracji dla polskiego ustawodawcy.

\section{Summary}

The article is on Austrian administrative court proceedings model, substantially changed in accordance with the amendment "Verwaltungsgerichtsbarkeits-Novelle 2012". In 2014 two-instances administrative judiciary was introduced including one court of first instance for each land as well as two federal administrative court of first instance. A significant change has occurred in jurisdictional competence of administrative courts. Now they can order on substantial issues. What's more thanks to introduction of courts of first instance ordering on substantial issues, the current administrative way is a one-stage one. Solutions adopted in Austria set the direction for development of administrative judiciary in Europe and could be inspiring for Polish legislator.

\section{Dagmara Gut}

Absolwentka filologii polskiej na Uniwersytecie Warszawskim oraz studentka V roku prawa na Uniwersytecie Kardynała Stefana Wyszyńskiego w Warszawie. Jej zainteresowania naukowe skupiają się wokół prawa i postępowania administracyjnego oraz sądowoadministracyjnego, prawa międzynarodowego oraz komparatystyki prawniczej. 